\title{
A new argasid tick species (Acari: Argasidae) associated with the rock cavy, Kerodon rupestris Wied-Neuwied (Rodentia: (aviidae), in a semiarid region of Brazil
}

Marcelo B. Labruna ${ }^{1 *}$, Santiago Nava², Arlei Marcili ${ }^{1,3}$, Amalia R. M. Barbieri ${ }^{1}$, Pablo H. Nunes ${ }^{4}$, Mauricio C. Horta ${ }^{5}$ and José M. Venzal ${ }^{6}$

\begin{abstract}
Background: The rock cavy Kerodon rupestris (Wied-Neuwied, 1820) is a rodent species endemic to northeastern Brazil. Earlier studies have associated the argasid tick Ornithodoros talaje (Guérin-Méneville, 1849) with rocky cavy; however, a recent study proposed that $O$. talaje is not established in Brazil, where previous reports of this species were possibly misidentifications of closely related species, yet to be properly determined. Here, we describe a new species of Ornithodoros Koch, 1844 associated with rock cavies in northeastern Brazil.

Methods: During 2012-2013, Ornithodoros ticks were collected from K. rupestris resting places in Paraíba State (PB) and Piauí State (PI), northeastern Brazil. These ticks were brought alive to the laboratory, and used to form two laboratory colonies (PB and PI ticks). Field-collected adults and laboratory-reared larvae were used for morphological description through light and scanning electron microscopy. DNA sequences of the mitochondrial 16S rRNA gene were generated from nymphal ticks and used to conduct phylogenetic analyses along with other Ornithodoros spp. sequences from GenBank. Reproductive compatibility of crosses between PB and PI adult ticks was evaluated, as well as analyses of hybrid ticks through larval morphology by a principal components analysis (PCA) and DNA sequences of the second internal transcribed spacer (ITS2) region from adult ticks.

Results: Morphological analysis allowed recognizing these ticks as a new species, Ornithodoros rietcorreai n. sp. The larva of $O$. rietcorreai is distinct from those of other Ornithodoros spp. by the combination of the following character states: 14 pairs of dorsal setae, dorsal plate pyriform, hypostome with pointed apex and dental formula 3/3 anteriorly, $2 / 2$ posteriorly, and anal valves with long and pointed leaf-shaped ends. There were a few larval morphological differences between PB and PI ticks, and their mitochondrial 165 rDNA sequences diverged by $3.3 \%$. On the other hand, cross-mating experiments showed that PB and PI ticks were reproductive compatible, indicating that they represent a single species. Analyses of ITS2 sequences and PCA corroborated this assumption.
\end{abstract}

Conclusion: Ornithodoros rietcorreai is described as a new species associated with K. rupestris in Brazil, increasing the Brazilian tick fauna to 70 species.

Keywords: Ornithodoros rietcorreai, Kerodon rupestris, Morphology, Mitochondrial 165 rDNA, ITS2

\footnotetext{
* Correspondence: labruna@usp.br

'Departamento de Medicina Veterinária Preventiva e Saúde Animal,

Faculdade de Medicina Veterinária e Zootecnia, Universidade de São Paulo,

Av. Prof. Orlando Marques de Paiva 87, São Paulo 05508-270, Brazil

Full list of author information is available at the end of the article
} 


\section{Background}

The rock cavy, Kerodon rupestris (Wied-Neuwied, 1820), is a rodent species endemic to the semiarid region (Caatinga biome) of northeastern Brazil. Adult rock cavies can weigh up to $1 \mathrm{~kg}$, body length reaching up to $40 \mathrm{~cm}$. They live in groups, inhabiting rocky areas with low, scrubby vegetation, typical of Caatinga hills, where they usually shelter in holes or crevices between rocks [1]. To the best of our knowledge, literature data about ticks infesting rock cavies under natural conditions have been restricted to a few earlier studies, which reported only two species on $K$. rupestris: the ixodid Amblyomma parvum Aragão, 1908 and the argasid Ornithodoros talaje (Guérin-Méneville, 1849) [2-4]. In addition, several collections of $O$. talaje from rock cavy resting places have been reported $[2,5,6]$.

Previous reports of $O$. talaje in Brazil relied primarily on morphological examination of adult and nymphal ticks [2-6]. In the subgenus Alectorobius, species morphological discrimination with certainty is usually possible only through the larval stage [7-9]. After subsequent studies during the 1960s and 1970s, it is currently accepted that the nymphal and adult stages of most of the 'New' World Ornithodoros species (including O. talaje) belonging to this subgenus cannot be accurately separated through morphological analysis. In addition, recent studies proposed that $O$. talaje is not established in Brazil, where previous reports of this species were possibly misidentification of closely related species, further reported during the last decades or yet to be described [10, 11].

In this study, we report Ornithodoros ticks associated with rock cavies in northeastern Brazil, including areas where this host was previously reported to be infested by $O$. talaje. Our results indicate a new Ornithodoros species, which we describe for the first time.

\section{Methods}

\section{Collection of ticks}

On 10 September 2012, we collected 24 Ornithodoros ticks from crevices in a rocky hill inhabited by wild $K$. rupestris in São José de Espinharas Municipality (06 $50^{\circ} \mathrm{S}, 37^{\circ} 24^{\prime} \mathrm{W}$; elevation: $\left.220 \mathrm{~m}\right)$, State of Paraíba (PB), northeastern Brazil. These ticks were brought alive to the laboratory, where they were used to form a laboratory colony, designated as PB ticks. On 22 January 2013, we collected 28 Ornithodoros ticks from crevices and the walls of a rocky hole inhabited by wild $K$. rupestris and bats (species not determined) in Jurema Municipality (0852'53.7"S, 4309'43.0"W; elevation $557 \mathrm{~m})$, State of Piauí (PI), northeastern Brazil. Another sample of 10 ticks was collected from a rocky hole $\left(08^{\circ} 53^{\prime} 27.4^{\prime \prime} \mathrm{S}, 4^{\circ} 07^{\prime} 53.4^{\prime \prime} \mathrm{W}\right.$; elevation $554 \mathrm{~m}$ ), also inhabited by $K$. rupestris and bats (species not determined), $3 \mathrm{~km}$ distant from the first locality of Jurema. These ticks were brought alive to the laboratory, where they were used to form two laboratory colonies, designated as PI-1 and PI-2 ticks.

\section{Morphological analyses}

Adult female ticks from two laboratory colonies (PB and PI-1) were fed on naïve hamsters in the laboratory and held in an incubator at $25{ }^{\circ} \mathrm{C}$ and a relative humidity of $80 \%$, where they laid egg masses that resulted in hatched larvae. Part of the unfed larvae $\left(\mathrm{F}_{1}\right)$, when 15-20 day-old, where killed in hot water and preserved in $70 \%$ ethanol for morphological analyses. For this purpose, unfed larvae from each colony were mounted in Hoyer's medium to make semi-permanent slides and examined by light microscopy using a Nikon Eclipse E200 optical microscope for morphological analysis and morphometry.

For the description, a total of 67 morphological features were observed and/or measured using 10 larvae from each colony (PB and PI-1). Larval terminology and measurements follow Kohls et al. [7] with the modifications proposed by Estrada-Peña et al. [12] and Venzal et al. [10]. Measurements are given in millimeters, with the range followed by the mean in parentheses. Five PB larvae were prepared for scanning electron microscopy as previously described [13].

Five adults of each sex from each of PB and PI-I tick colonies were measured under a stereoscope microscope with the use of the Image-Pro Plus 5.1 program for analysis of images and morphometry, fitted to an Olympus SZX stereoscope microscope (Olympus Corporation, Tokyo, Japan). Two PB adults of each sex were prepared for scanning electron microscopy following previously described techniques [14]. Photomicrographs were taken with a Hitachi TM3000 scanning electron microscope (Hitachi High-Technologies Corporation, Tokyo, Japan).

The type-series of the tick species described in this study has been deposited in the following tick collections: United States National Tick Collection, Statesboro, GA, United States (USNMENT, CEN); "Coleção Nacional de Carrapatos", University of São Paulo, SP, Brazil (CNC); Acari Collection of the Butantan Institute, University of São Paulo, SP, Brazil (IBSP); Department of Veterinary Parasitology, Faculty of Veterinary, Salto, Uruguay (DPVURU); Instituto Nacional de Tecnología Agropecuaria, Rafaela, Santa Fe, Argentina (INTA).

\section{Molecular and phylogenetic analyses}

Two nymphs of each of the three tick colonies (PB, PI-1, and PI-2) were used for molecular analysis. For this purpose, each individual tick was subjected to DNA extraction with DNeasy Tissue Kit (Qiagen, Valencia, California), and processed by polymerase chain 
reaction (PCR) with the use of primers targeting $\mathrm{a} \approx$ $460 \mathrm{bp}$ fragment of the tick 16S rDNA mitochondrial gene, as previously described [15]. PCR products of the expected size were sequenced in an $\mathrm{ABI}$ automated sequencer (Applied Biosystems/Thermo Fisher Scientific, model ABI 3500 Genetic Analyzer, Foster City, California, USA) with the same primers used for PCR. The newly-generated sequences were compared to each other and submitted to BLAST analyses (www.ncbi.nlm.nih.gov/blast) to infer closest similarities available in GenBank.

The 16S rDNA mitochondrial gene partial sequences generated in this study were deposited in the GenBank database under accession numbers KX130781 and KX130782. These sequences were manually aligned using GeneDoc software (http://www.nrbsc.org/downloads/) with sequences previously determined for other argasid species available in GenBank, and also with sequences of Ixodes holocyclus Neumann, 1899 and Ixodes uriae White, 1852 (Ixodidae) that were used as a distant outgroup. The phylogenetic tree was inferred by the maximum parsimony method using PAUP version $4.0 \mathrm{~b} 10$ [16] with 500 replicates of random addition taxa and tree bisection and reconnection branch swapping; all positions were given equal weight.

\section{Biological analyses and cross-mating assays}

Part of the unfed larvae $\left(F_{1}\right)$ hatched from eggs laid by PB and PI-1 tick colonies were reared separately until the $F_{1}$ adult stage in the laboratory. For this purpose, one ticknaïve hamster (Mesocricetus auratus Waterhouse, 1839) or vesper mouse [Calomys callosus (Rengger, 1830)] was used for feeding of each tick stage of each tick colony, except for N1 nymphs, which molted to N2 without feeding. Engorged N3 nymphs were held separately from each other by placing each tick inside a well of a 96-well plate covered by a plastic cover. Under this condition, the adult ticks (males and females) that emerged from N3 nymphs did not have the chance to copulate. While some N3 nymphs molted to $\mathrm{N} 4$ nymphs, only adult ticks that emerged from N3 nymphs were used for the crossbreeding assays.

Virgin, adult unfed $F_{1}$ ticks were sorted in four plastic vials as follows: 5 PB males with 6 PB females in a vial ( ${ }^{7} \mathrm{~PB} \times \propto$ PB homologous cross); 8 PI-I males with 7 PI-I females in a vial ( $\mathcal{O}^{-} \mathrm{PI} \times \propto$ PI homologous cross); $5 \mathrm{~PB}$ males with 7 PI-I females $(\delta \mathrm{PB} \times \bigcirc \mathrm{PI}$ heterologous cross), and 8 PI-I males with $6 \mathrm{~PB}$ females $\left({ }^{\wedge} \mathrm{PI} \times{ }^{2} \mathrm{~PB}\right.$ heterologous cross). These vials were left in the incubator for 14 days. After this period, adults of each cross were fed on a hamster; then, 3 to 4 couples from each cross were placed in different vials (1 couple per vial). When the female of each couple laid eggs, the hatched larvae $\left(\mathrm{F}_{2}\right.$ ticks $)$ were reared until the adult stage, representing $\mathrm{F}_{2}$ adult ticks that came from a single female. These $F_{2}$ adult ticks (males and females) were fed on a hamster and held together in a vial to verify their fertility. In parallel, a sample of $3 F_{1}$ female ticks from either PB or PI colonies was always held without males (both before and after feeding on hamster) in order to verify if these ticks could reproduce by parthenogenesis.

\section{Morphological and molecular analyses of cross-mating ticks}

Larvae $\left(\mathrm{F}_{3}\right)$ produced by $\mathrm{F}_{2}$ adult ticks of all four crosses

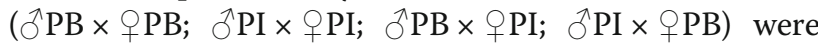
killed in hot water, preserved in $70 \%$ ethanol, and then mounted in Hoyer's medium to make semi-permanent slides and examined by light microscopy for morphological and morphometric analyses, as described above for $\mathrm{F}_{1}$ larvae.

After the fertility tests, $F_{2}$ adult ticks of all four crosses were subjected to DNA extraction as described above and processed by PCR targeting the second internal transcribed space (ITS2) of the tick ribosomal DNA. For this purpose, we used the primers Forward (5'-GGT GTG AAT TGC AGG ACA CAC TG-3'), corresponding to the $5.8 \mathrm{~S}$ rDNA gene, and Reverse ( $5^{\prime}$-AGA TCA GGC GAG ACA ACC CGC-3'), corresponding to the 5' end of the $28 \mathrm{~S}$ rDNA gene. These primers were designed in this study to amplify a fragment of $\approx 550$ bp of Ornithodoros ticks (unpublished data), which includes the complete ITS2 region $(\approx 430 \mathrm{bp})$. PCR products of the expected sizes were cloned by using the TA Cloning kit (Invitrogen, Carlsbad, California, USA) following the manufacturer's instructions. Plasmids containing the DNA inserts of the expected size were sequenced at least four times by using an $\mathrm{ABI}$ automated sequencer with M13 forward and M13 reverse sequencing primers (Invitrogen). One to four colonies generated from each individual tick (at least one male and one female from each cross) were analyzed.

The ITS2 nucleotide sequences generated in this study were deposited in the GenBank database under accession numbers KX130784-KX130800. The entire ITS2 sequences generated from all clones of each tick specimen were manually aligned using GeneDoc software, and a phylogenetic tree was inferred by the maximum parsimony method using PAUP version $4.0 \mathrm{~b} 10$ with 500 replicates of random addition taxa and tree bisection and reconnection branch swapping; all positions were given equal weight.

\section{Principal components analysis}

A principal components analysis (PCA) based on a Pearson's correlation matrix was applied on 44 morphometric variables for larvae from both homologous and heterologous crosses to elucidate relationships among the two tick populations. In addition, we included 
data from the larvae of O. talaje, Ornithodoros rioplatensis Venzal, Estrada-Peña \& Mangold, 2008, and Ornithodoros guaporensis Nava, Venzal \& Labruna, 2013, all retrieved from Nava et al. [17]. Raw measurements were $\log (x+1)$-transformed to standardize variances and improve normality.

\section{Results}

Order Ixodida Leach, 1815

Family Argasidae Canestrini, 1890

Genus Ornithodoros Koch, 1844

Ornithodoros rietcorreai Labruna, Nava \& Venzal n. sp.

Type-host: While all ticks were collected from the environment, they were collected from rocky holes inhabited by $K$. rupestris and bats (Piauí), and in a rocky hill inhabited by $K$. rupestris (Paraíba). These findings suggest that $K$. rupestris, and bats to a lesser extent, serve as hosts for O. rietcorreai $\mathrm{n}$. sp., a statement yet to be confirmed.

Type-locality: Jurema Municipality, State of Piauí, Brazil (08'52'53.7"S, 4309'43.0"W; elevation $557 \mathrm{~m}$ ).

Other localities: São José de Espinharas Municipality, State of Paraíba, Brazil (06 $50^{\circ} \mathrm{S}, 37^{\circ} 24^{\prime} \mathrm{W}$; elevation $\left.220 \mathrm{~m}\right)$.

Type-specimens: Holotype: one unfed larva, originated from egg laid in the laboratory by paratype female collected in Jurema Municipality, State of Piauí, Brazil, 22.i.2013, by M. B. Labruna (holotype larva mounted in a slide with other 10 non-paratype larvae). Deposited in the United States National Tick Collection, Statesboro, GA, United States (USNMENT00862200, CEN125635). Paratypes (an asterisk indicates that the specimen was measured): five females*, five males*, collected in rocky hole inhabited by Kerodon rupestris and bats $\left(08^{\circ} 52^{\prime}\right.$ 53.7" S, 4309' 43.0"W; elevation $557 \mathrm{~m}$ ), Jurema Municipality, State of Piauí, Brazil, 22.i.2013, by M. B. Labruna (CNC-3264, 3265, 3266); five females*, five males*, collected in a rocky hill inhabited by $K$. rupestris $\left(06^{\circ}\right.$ $50^{\prime}$ S, $37^{\circ} 24^{\prime} \mathrm{W}$; elevation $220 \mathrm{~m}$ ), São José de Espinharas Municipality, State of Paraíba, Brazil, 10.ix.2012, by M. B. Labruna, S. Nava, J. M. Venzal (CNC-3267, IBSP12476, USNMENT00862764, CEN125636); ten unfed larvae*, originated from eggs laid in the laboratory by paratype females collected in São José de Espinharas Municipality, State of Paraíba, as stated above (DPVURU879); nine unfed larvae* and 45 unfed larvae, originated from eggs laid in the laboratory by paratype females collected in Jurema Municipality, State of Piauí, as stated above (DPVURU-880); 64 unfed larvae, originated from eggs laid in the laboratory by paratype females collected in Jurema Municipality, State of Piauí, as stated above (CNC3268, INTA-2329, IBSP-12477, USNMENT0086276200862763, CEN125635); ten males, two females, two nymphs (these nymphs were destroyed for DNA extraction) collected in São José de Espinharas Municipality, State of Paraíba, as stated above (CNC-3273); five males, three females, ten nymphs (two of these nymphs were destroyed for DNA extraction) collected in Jurema Municipality, State of Piauí, as stated above (CNC-3270); 74 unfed larvae, originated from eggs laid in the laboratory by paratype females collected in São José de Espinharas Municipality, State of Paraíba, as stated above (CNC-3271); 32 unfed larvae, originated from eggs laid in the laboratory by paratype females collected in Jurema Municipality, State of Piauí, as stated above (CNC-3269); five males, one female, four nymphs (two of these nymphs were destroyed for DNA extraction) collected in a rocky hole inhabited by $K$. rupestris and bats

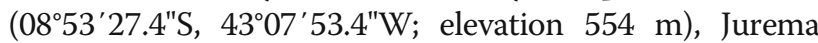
Municipality, State of Piauí, Brazil, 23.i.2013, by M. B. Labruna (CNC-3272).

Representative DNA sequences: Mitochondrial 16S rRNA gene, partial sequences: GenBank accession numbers KX130781-KX130782; second internal transcribed spacer (ITS2) of the nuclear ribosomal DNA, complete sequences: GenBank accession numbers KX130784- KX130800.

ZooBank registration: Details of the new species have been submitted to ZooBank (http://zoobank.org/). The Life Science Identifier (LSID) of the article is urn:lsid:zoobank. org:act:106221A8-3781-48DA-B63C-98F4D91BFAAD. The LSID for the new name Ornithodoros rietcorreai is urn:lsid: zoobank.org:act:8A6D9021-22D4-447C-A9BA-85FADED 53A9C.

Etymology: The species is named for Professor Franklin Riet-Correa, veterinary pathologist, for his outstanding contributions to the scientific development (including parasitology) in the Caatinga biome, where this new species was discovered.

\section{Description}

Larva. [Figs. 1, 2 and 3; measurements based on the holotype and 9 paratypes from Piauí (PI-1 ticks) and 10 paratypes from Paraíba (PB ticks).]

Body: Idiosoma oval. Length including capitulum 0.723-0.841 (0.777), length excluding capitulum 0.3960.475 (0.448), width 0.372-0.465 (0.403). Dorsum: Dorsal plate pyriform, posterior margin slightly concave, length $0.256-0.305$ (0.275), width 0.151-0.219 (0.182).

Dorsal surface provided with 14 pairs of setae, seven anterolateral, three central and four posterolateral. Anterolateral setae $(\mathrm{Al})$ : $\mathrm{Al}_{1}$ length 0.061-0.078 (0.069), $\mathrm{Al}_{2}$ length $0.061-0.075$ (0.068), $\mathrm{Al}_{3}$ length 0.061-0.078 (0.067), $\mathrm{Al}_{4}$ length $0.058-0.078$ (0.066), $\mathrm{Al}_{5}$ length 0.056 0.073 (0.067), $\mathrm{Al}_{6}$ length 0.063-0.080 (0.071), $\mathrm{Al}_{7}$ length 0.073-0.085 (0.079). Central setae $(C)$ : $C_{1}$ length 0.0630.090 (0.078), $C_{2}$ length 0.068-0.075 (0.071), $C_{3}$ length $0.073-0.088(0.079)$. Posterolateral setae $(\mathrm{Pl}): \mathrm{Pl}_{1}$ length 0.063-0.078 (0.072), $\mathrm{Pl}_{2}$ length 0.063-0.081 (0.071), $\mathrm{Pl}_{3}$ length $0.058-0.083$ (0.069), $\mathrm{Pl}_{4}$ length $0.061-0.075$ (0.068). 

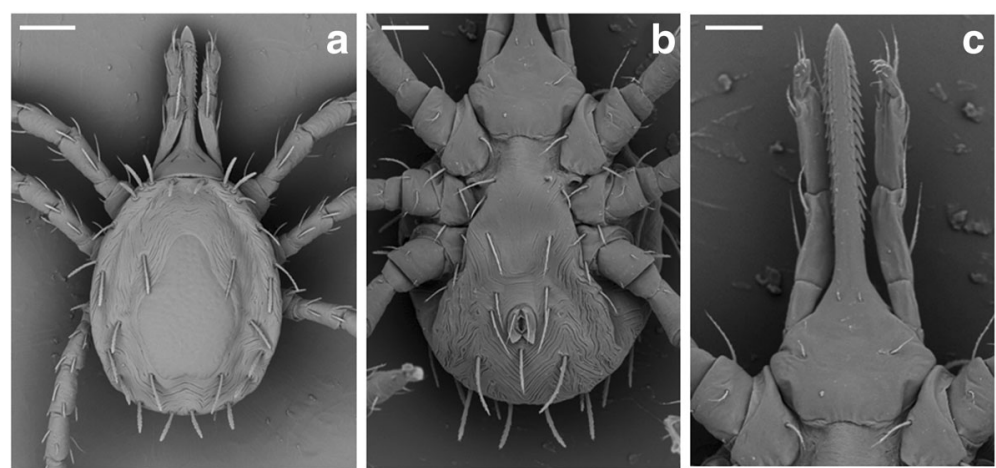

Fig. 1 Scanning electron micrographs of Ornithodoros rietcorreai n. sp. Larva. a Unengorged specimen, dorsal view. b Unengorged specimen, ventral view. c Ventral capitulum. Scale-bars: a, b, $100 \mu \mathrm{m} ; \mathbf{c}, 50 \mu \mathrm{m}$

Venter: Ventral surface provided with seven pairs of setae plus 1 pair on anal valves, one posteromedian seta present. Anal valves with long and pointed leaf-shaped ends. Three pairs of sternal setae $(\mathrm{St})$ : $\mathrm{St}_{1}$ length $0.051-$ 0.073 (0.063), $\mathrm{St}_{2}$ length $0.051-0.068$ (0.061), $\mathrm{St}_{3}$ length $0.056-0.075$ (0.065); three pairs of circumanal setae (Ca): $\mathrm{Ca}_{1}$ length $0.053-0.071(0.058)$, $\mathrm{Ca}_{2}$ length $0.058-$ 0.075 (0.069), $\mathrm{Ca}_{3}$ length 0.073-0.085 (0.078); posteromedian setae (PM) length $0.053-0.073$ (0.063), postcoxal setae ( $\mathrm{Pc}$ ) length 0.041-0.051 (0.045).

Capitulum: Basis capituli hexagonal, posterior margin straight. Length from posterior margin of basis capituli to posthypostomal setae: $\mathrm{Ph}_{1}$ 0.129-0.149 (0.138), length from posterior margin of basis capituli to insertion of hypostome 0.154-0.173 (0.163), length from posterior margin of basis capituli to apex of hypostome 0.362-0.406
(0.385), width $0.185-0.210$ (0.197). Two pairs of posthypostomal setae; $\mathrm{Ph}_{1}$ length 0.019-0.024 (0.021), $\mathrm{Ph}_{2}$ length 0.039-0.056 (0.046), distance between $\mathrm{Ph}_{1}$ setae 0.0190.024 (0.023), distance between $\mathrm{Ph}_{2}$ setae 0.071-0.083 (0.075). Palpal total length 0.264-0.294 (0.277), segmental length/width from I-IV: (I) $0.049-0.061(0.057) / 0.027-$ $0.039 \quad(0.030), \quad$ (II) $\quad 0.083-0.100 \quad(0.088) / 0.034-0.044$ (0.037), (III) 0.088-0.107 (0.099)/0.024-0.034 (0.030), (IV) 0.036-0.044 (0.040)/0.019-0.024 (0.021). Setal number on palpal articles I-IV: (I) 0, (II) 4, (III) 5, (IV) 9. Hypostome: length from $\mathrm{Ph}_{1}$ to apex 0.232-0.256 (0.248), length from insertion of hypostome in basis capituli to apex $0.207-0.236(0.225)$, length to inferior toothed portion to apex $0.190-0.212(0.204)$, width in medial basis portion of hypostome $0.044-0.056(0.049)$, width in basis portion of hypostome $0.039-0.051$ (0.044), pointed

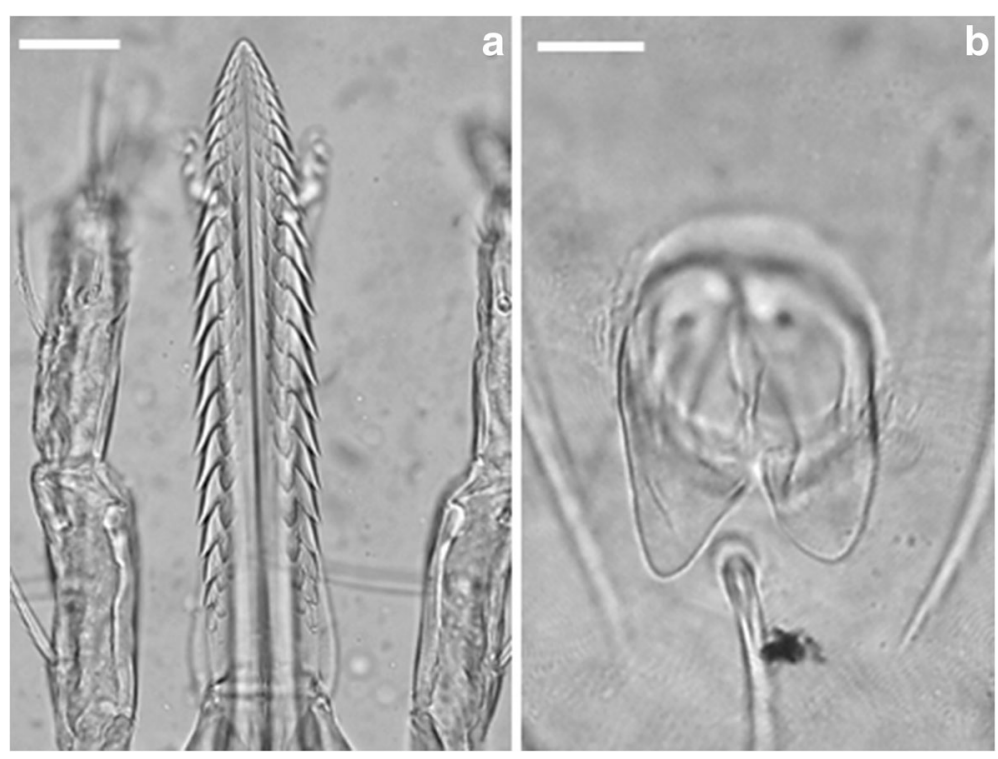

Fig. 2 Light microscopy photomicrographs of Ornithodoros rietcorreai n. sp. Larva. a Hypostome. b Anal valves. Scale-bars: $25 \mu \mathrm{m}$ 


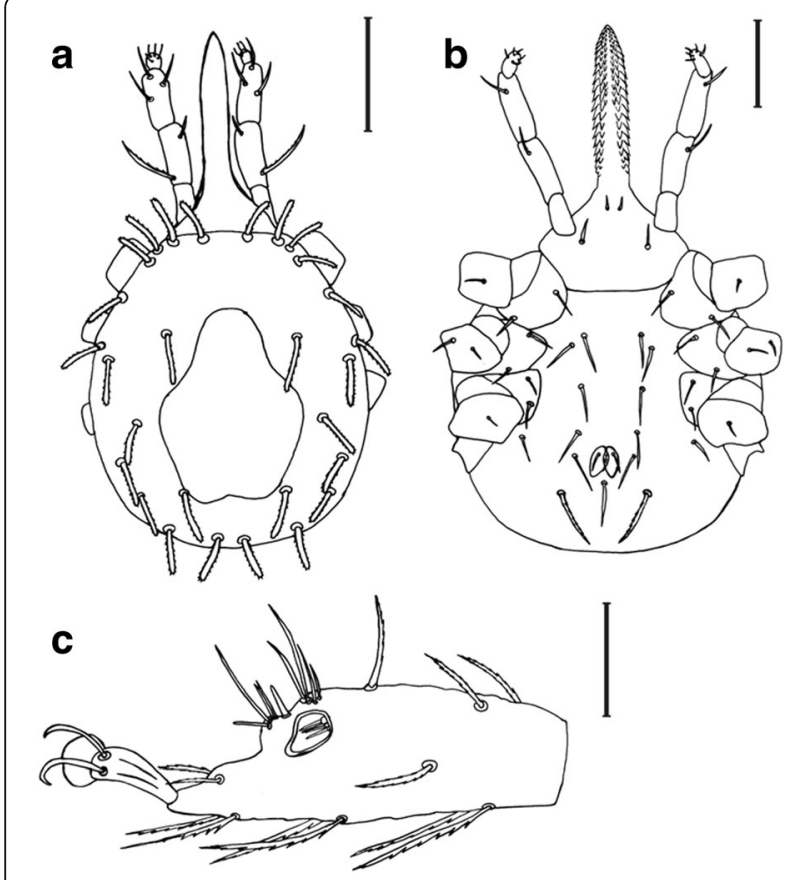

Fig. 3 Line drawing of Ornithodoros rietcorreai n. sp. Larva. a Dorsal view. b Ventral view. c Tarsus I. Scale-bars: a, b, $150 \mu \mathrm{m} ; \mathbf{c}, 50 \mu \mathrm{m}$

apically. Dental formula $3 / 3$ in the anterior half, $2 / 2$ posteriorly almost to base. Dentition: denticles absent from a part at the base. File one with 20 to 21 denticles (typically 21), file two with 20 to 21 (typically 21), and file three with 12 to 15 (typically 14).

Legs: Tarsus I length $0.158-0.202$ (0.181), tarsus I width $0.049-0.068(0.060)$. Setal formula of tarsus I: one pair apical (A), one distomedian (DM), five paracapsular (PC), one posteromedian (PM), one pair basal (B), one pair apicoventral (AV), one pair midventral (MV), one pair basiventral (BV), and one pair posterolateral (PL). Capsule of Haller's organ without reticulations.

Female. [Fig. 4; measurements based on five paratypes from Piauí (PI-1 ticks) and five paratypes from Paraíba (PB ticks).]

Dorsal: Body outline elliptical, pointed anteriorly, curve of posterior border slightly flattened, sides nearly parallel. Length from pointed anterior end to posterior body margin 5.145-6.639 (5.691), breadth 3.254-4.618 (3.730). Submarginal grooves distinct, fused anteriorly. Mammillae large, crowded, irregular in shape, slightly elevated, with short hairs, usually one or two hairs per mammilla. Distinct discs, covered by flattened mammillae in slightly depressed areas over medium area within marginal grooves present.

Ventral: Mammillae as dorsally. Genital opening semilunar in shape at level of coxa I, reaching level of the anterior margin of coxa II. Preanal and transverse postanal grooves present; medium postanal groove indicated by depression terminating at transverse postanal groove; coxal folds extending from space between coxae I and II to near level of anus, where they diverge to posterolateral angles. Anal plate nearly elliptical. Spiracular plate above coxa IV. Small rounded hood; camerostome indistinct; cheeks well developed, with irregular wrinkles, covering mouth parts partially or almost completely.

Capitulum: Basis capituli slightly wider than long, with irregular transverse wrinkles and micromammillated. Palpi moderate in size, with various long setae; article one micromammillated with ventro-medial integumental ridge-like extension covering part of hypostomal base. Hypostome rounded apically with a central notch, reaching to level of articulation of palpal articles three and four. Hypostomal dentition 2/2 with 6-8 denticles per row; toothed portion starting at level of articulation of palpal articles one and two.

Legs: Long, with micromammillated surface; coxae I-II with various mammillae; coxae III-IV with few mammillae over micromammillated surface. Small setae sparsely distributed through articles. Coxa I well separated by coxa II by an inter-coxal fold, coxae II-IV contiguous. Tarsi I-IV with a discrete subapical dorsal protuberance, dorsal humps absent; stout claws and small pulvilli present. Anterior tip of Haller's organ with distinct anterior and posterior sections; capsule opening transverse, slitlike.

Male. [Fig. 5; measurements based on five paratypes from Piauí (PI-1 ticks) and five paratypes from Paraíba (PB ticks)]

Dorsal: Length from pointed anterior end to posterior body margin 4.110-5.298 (4.659), breadth 3.235-3.565 (3.052). Other features as in female.

Ventral: Genital opening with a flap in the form of half circle, located at level of coxa I. Other features as in females.

Capitulum: As in females.

Legs: As in females.

\section{Distribution}

The geographical distribution of $O$. rietcorreai is restricted to the Caatinga biome in northeastern Brazil, where this tick species was found in two municipalities (in Paraíba and Piauí states), at a distance of $\approx 670 \mathrm{~km}$ from each other. Since populations of $K$. rupestris are widespread in the Caatinga biome [1], it is possible that the geographical distribution of $O$. rietcorreai encompasses additional areas within this biome.

\section{Remarks}

Ornithodoros rietcorreai n. sp. belongs to the subgenus Alectorobius Pocock, 1907 because adults possess cheeks, a typical character for this subgenus, and larvae 

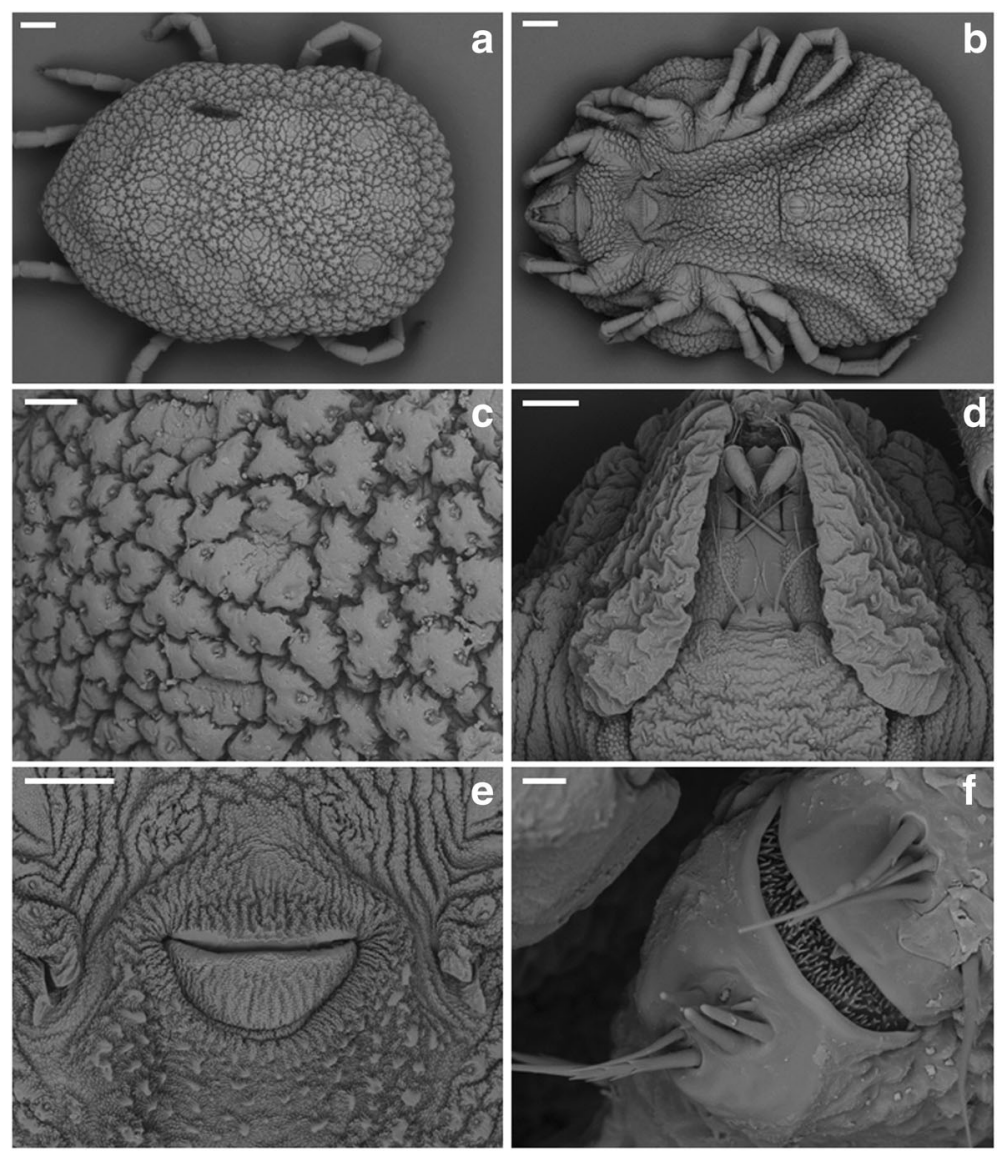

Fig. 4 Scanning electron micrographs of Ornithodoros rietcorreai n. sp. Female. a Dorsal idiosoma. b Ventral idiosoma. c Detail on dorsal integument. d Ventral capitulum. e Genital opening. f Haller's organ. Scale-bars: a, b, $400 \mu \mathrm{m} ; \mathbf{c}, \mathbf{d}, 100 \mu \mathrm{m} ; \mathbf{e}, 200 \mu \mathrm{m} ; \mathbf{f}, 10 \mu \mathrm{m}$

possess the most typical characters (not exclusive) for the subgenus Alectorobius: dorsal plate pyriform, dorsal body surface with 11 to 18 pairs of dorsolateral setae, usually barbed, ventral body surface with 8 or 9 pairs of setae plus a posteromedian seta, and hypostome pointed with dentition $3 / 3$ to $5 / 5$ anteriorly, $2 / 2$ posteriorly to base [18]. Differentiation of species of Alectorobius by the features of the adult stage is complicated in many cases [7-9]; therefore the larval stage is indicated for species identification through morphological analysis. The larva of $O$. rietcorreai is distinct from the previously described Ornithodoros spp. due to the combination of the following characters: 14 pairs of dorsal setae (7 anterolateral, 3 central and 4 posterolateral pairs), dorsal plate pyriform (length $c .0 .275 \mathrm{~mm}$ ), hypostome with pointed apex and dental formula $3 / 3$ in the anterior half, $2 / 2$ posteriorly almost to base, and anal valves with long and pointed leaf-shaped ends. On the other hand, the larva of $O$. rietcorreai $\mathrm{n}$. sp. is similar to the species included in the $O$. talaje species group. The larva in this group is characterised by the presence of a pyriform dorsal plate, pointed hypostome, and 17-20 pairs of dorsal setae $[19,20]$. Contrastingly, O. rietcorreai larvae have 14 pairs of dorsal setae. Other Neotropical species of Ornithodoros with 14 pairs of dorsal setae in the larval stage are Ornithodoros dyeri Cooley \& Kohls, 1940, Ornithodoros fonsecai (Labruna \& Venzal, 2009), Ornithodoros knoxjonesi Jones \& Clifford, 1972, Ornithodoros rossi Kohls, Sonenshine \& Clifford, 1965, Ornithodoros peropteryx Kohls, Clifford \& Jones, 1969, Ornithodoros peruvianus Kohls, Clifford \& Jones, 1969, Ornithodoros yumatensis Cooley \& Kohls, 1941, and Ornithodoros yunkeri Keirans, Clifford \& Hoogstraal, 1984. Larvae of O. dyeri, O. rossi and $O$. yunkeri can be differentiated from $O$. rietcorreai by the presence of four pairs of circumanal setae on the ventral idiosoma in the former two species, and the absence of the posteromedian seta in O. yunkeri. Larvae of $O$. knoxjonesi and $O$. peropteryx possess a constriction near the hypostome mid-length, which is absent in the hypostome of $O$. rietcorreai.

Larvae of $O$. fonsecai are clearly larger (mean body length $1.020 \mathrm{~mm}$; range: $0.990-1.050 \mathrm{~mm}$ ) than the larvae of $O$. 

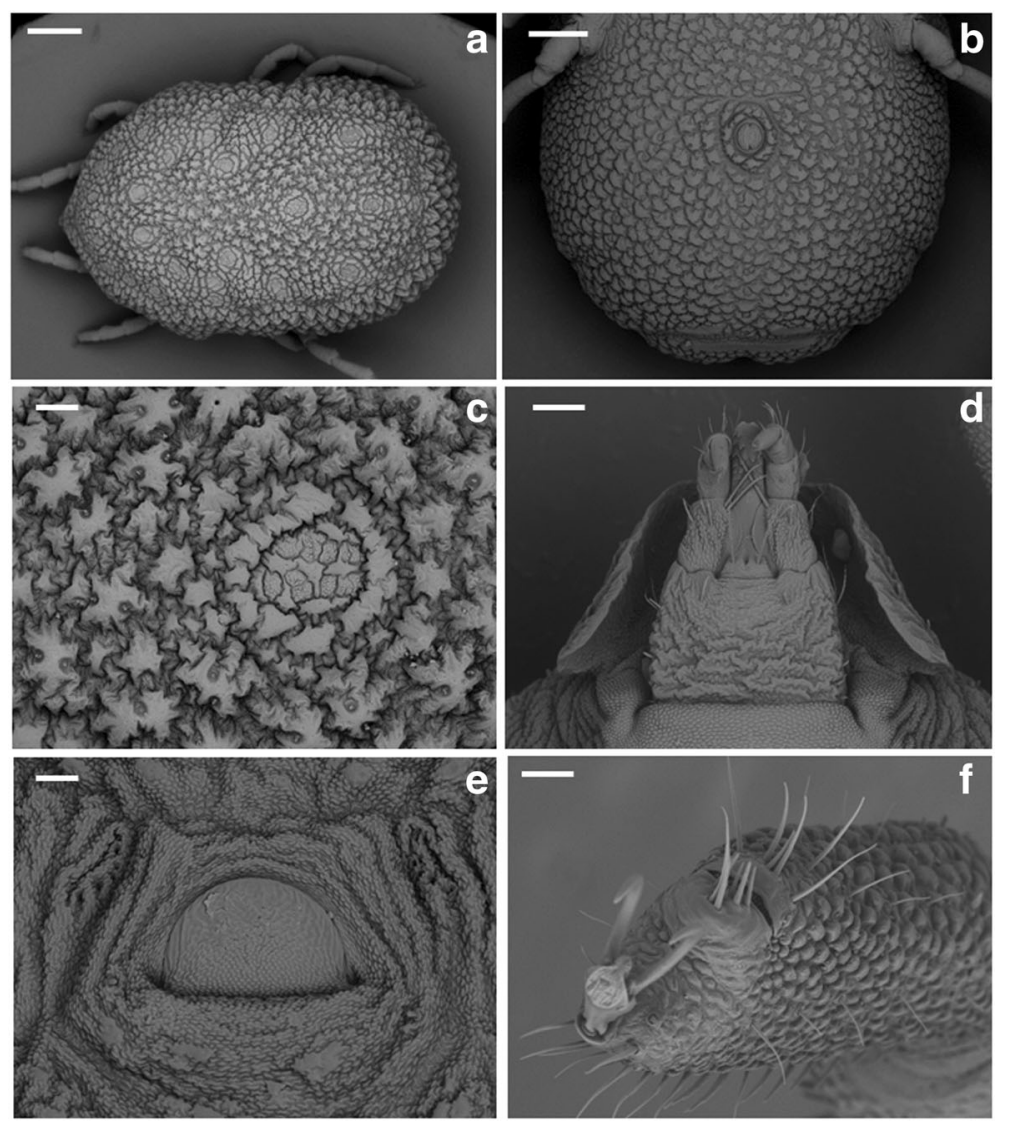

Fig. 5 Scanning electron micrographs of Ornithodoros rietcorreai n. sp. Male. a Dorsal idiosoma. b Posterior part of ventral idiosoma. $\mathbf{c}$ Detail on dorsal integument. d Ventral capitulum. e Genital opening. f Tarsus I showing Haller's organ. Scale-bars: a, $600 \mu \mathrm{m} ; \mathbf{b}, 400 \mu \mathrm{m} ; \mathbf{c}, \mathbf{d}, 100 \mu \mathrm{m} ; \mathbf{e}, 60 \mu \mathrm{m} ; \mathbf{f}, 30 \mu \mathrm{m}$

rietcorreai (mean $0.777 \mathrm{~mm}$; range: $0.723-0.841 \mathrm{~mm}$ ). Ornithodoros peruvianus and O. yumatensis differ from $O$. rietcorreai by their larger dorsal plate (mean $>0.310 v \mathrm{~s}$ $0.275 \mathrm{~mm}$ ). Additionally, O. peruvianus possess fringed setae in tarsus I, and the capsule of Haller's organ is reticulated in O. yumatensis. Finally, O. rietcorreai larvae have anal valves with long and pointed leaf-shaped ends, a feature not present in any of the above mentioned species.

While O. riecorreai is phylogenetically closely related to Ornithodoros quilinensis Venzal, Nava \& Mangold, 2012, Ornithodoros xerophylus Venzal, Mangold \& Nava, 2015 and Ornithodoros kohlsi Gugliemone \& Keirans, 2002 (Fig. 6), the larva of the later species has 19 pairs of dorsal setae (in contrast to 14 in $O$. rietocorreai), and the larvae of both $O$. quilinensis and O. xerophylus possess a blunt hypostome, in contrast to the pointed hypostome in $O$. rietcorreai $\mathrm{n}$. sp.

\section{Molecular and phylogenetic analyses}

A fragment of the $16 \mathrm{~S}$ rDNA mitochondrial gene was generated from two nymphs from each of the three localities (PB, PI-1, and PI-2). The two PB nymphs generated an identical haplotype of 426 nucleotides (KX130781), whereas the four PI nymphs (2 PI-I and 2 PI-2) generated an identical haplotype of 427 nucleotides (KX130782). These two distinct haplotypes were $96.7 \%(413 / 427)$ similar to each other. By BLAST analyses, these haplotypes were most similar (88-89 \%) to the sequences available on GenBank for Ornithodoros capensis Neumann, 1901 (e.g. JQ824304, AB242431, AB075953) and Ornithodoros sawaii Kitaoka \& Suzuki, 1973 (e.g. KP899267, KT372792, KP730692). Phylogenetic relationships inferred by analysis of partial sequences of the mitochondrial 16S rDNA gene (Fig. 6) placed the two haplotypes of $O$. rietcorreai n. sp. together and basal to the sequences of $O$. kohlsi from Bolivia, O. quilinensis from Argentina, Ornithodoros sp. from Bolivia and O. xerophylus from Argentina. This clade was sister to Ornithodoros lahillei Venzal, González-Acuña \& Nava, 2015 from Chile, and then to O. capensis, O. sawaii and Ornithodoros microplophi Venzal, Nava \& González-Acuña, 2013.

\section{Biological analyses and cross-mating assays}

Larvae of $O$. rietcorreai fed for 4 to 7 days on $C$. callosus hosts, with the majority $(\approx 80 \%)$ of engorged larvae 


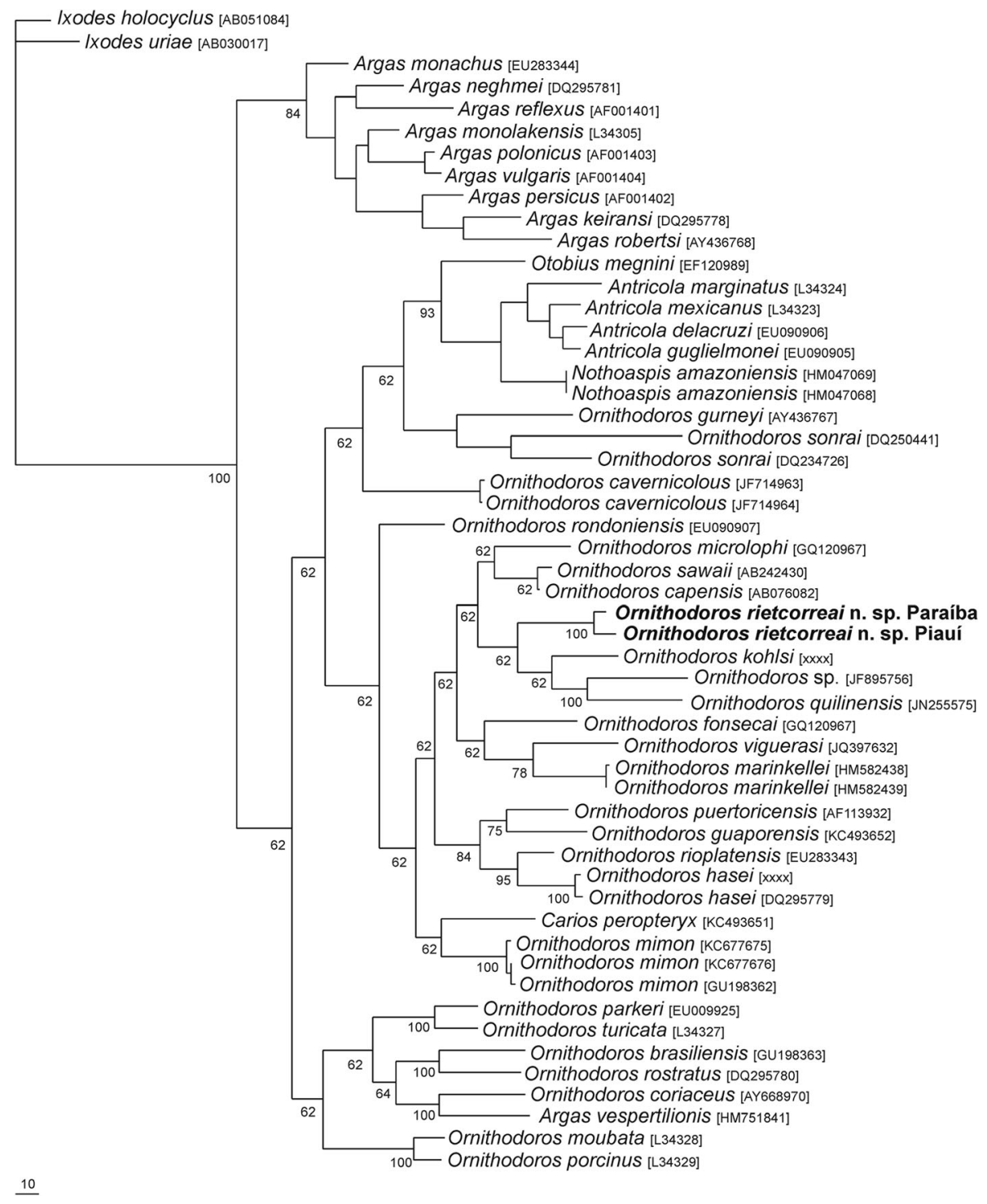

Fig. 6 Maximum parsimony (MP) phylogenetic tree based on partial 16S rDNA sequences for Ornithodoros rietcorreai n. sp. and other argasid tick species. Ixodes uriae and I. holocyclus were used as the outgroup. Numbers at nodes represent support values derived from bootstrap (500 replicates)

detaching on the 5 th feeding day. At $25{ }^{\circ} \mathrm{C}$ and relative humidity (RH) of $80 \%$, engorged larvae took 5-7 days to molt to N1 nymphs, which molted to N2 nymphs (without feeding) in 10-12 days. These N2 nymphs fed on hamsters in less than $30 \mathrm{~min}$, and then took $21-23$ days to molt to N3 nymphs. These later nymphs fed on hamsters in less than $30 \mathrm{~min}$, and took $20-25$ days to molt to N4 nymphs, adult males, or adult females. These adult ticks were used for the cross-mating assays.

Results from the crosses with the O. rietcorreai colonies from Paraiba State (PB) and Piauí State (PI) are shown in Table 1. After feeding for up to $60 \mathrm{~min}$ on hamsters, $F_{1}$ males and females were sorted in couples

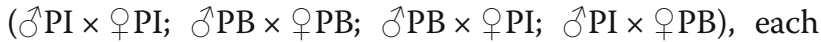

couple within a plastic vial. Females from each single couple of either homologous or heterologous crosses produced viable offspring, as numerous highly motile larvae (they were not counted) appeared in each vial between 30 to 60 days after female feeding. The hatched larvae $\left(F_{2}\right.$ ticks $)$ were reared until the adult stage, which also produced viable offspring ( $\mathrm{F}_{3}$ larvae). None of the $F_{1}$ female ticks was able to oviposit without previous contact with males, indicating lack of parthenogenesis in this tick species.

\section{Molecular analyses of cross-mating ticks}

ITS2 sequences were generated from male and female ticks of each of the four cross-mating groups. Regarding 
Table 1 Results of cross-mating experiments of $F_{1}$ adult ticks of two laboratory colonies of Ornithodoros rietcorreai n. sp., one from the state of Piauí (PI), and one from the State of Paraíba (PB), Brazil

\begin{tabular}{|c|c|c|c|c|}
\hline Cross $(\hat{a} \times q)$ & No. of $F_{1}$ adult pairs & No. of $F_{1}$ females that oviposited (\%) & No. of females that generated $F_{2}$ larvae & Fertility of $F_{2}$ adults \\
\hline$\overline{\mathrm{Pl} \times \mathrm{PI}}$ & 4 & $4(100)$ & $4(100)$ & Yes $^{a}$ \\
\hline$P B \times P B$ & 3 & $3(100)$ & $3(100)$ & Yes $^{a}$ \\
\hline $\mathrm{PB} \times \mathrm{PI}$ & 4 & $4(100)$ & $4(100)$ & Yes $^{\mathrm{a}}$ \\
\hline $\mathrm{PI} \times \mathrm{PB}$ & 3 & $3(100)$ & $3(100)$ & Yes $^{\mathrm{a}}$ \\
\hline$-\times \mathrm{PB}^{\mathrm{b}}$ & 3 & $0(0)$ & $0(0)$ & - \\
\hline$-\times \mathrm{Pl}^{\mathrm{b}}$ & 3 & $0(0)$ & $0(0)$ & - \\
\hline
\end{tabular}

${ }^{a}$ Five male and five female $F_{2}$ adults from each $F_{1}$ cross were left together in a vial after a blood meal; numerous larvae were born in each vial several weeks later, confirming fertility of $F_{2}$ adults

${ }^{\mathrm{b}}$ These groups consisted of only females with no contact with males, with the purpose to verify if female ticks could reproduce by parthenogenesis after a blood meal

ticks derived from the homologous crosses (purebred), three distinct haplotypes (A, B, C) were generated from the $\mathrm{PI} \times q \mathrm{PI}$ ticks, and seven distinct haplotypes (D, E, F, G, H, I, J) were generated from the ${ }^{7} \mathrm{~PB} \times \propto \mathrm{PB}$ ticks. No haplotype was shared by the two homologous crosses. Among ticks derived from the ${ }^{\top} \mathrm{PB} \times \uparrow \mathrm{PI}$ heterologous crosses (hybrids), five haplotypes were generated, three unique $(\mathrm{K}, \mathrm{M}, \mathrm{L})$ and two $(\mathrm{E}, \mathrm{H})$ also found in the homologous ${ }^{7} \mathrm{~PB} \times+\mathrm{PB}$ ticks. Among ticks derived from the ${ }^{7} \mathrm{PI} \times \propto \mathrm{PB}$ heterologous crosses (hybrids), six haplotypes were generated, four unique $(\mathrm{N}, \mathrm{O}, \mathrm{P}, \mathrm{Q})$ and two $(\mathrm{E}, \mathrm{H})$ also found in the homologous ${ }^{\top} \mathrm{PB} \times \uparrow \mathrm{PB}$ ticks (Table 2). Generally, the same individual tick contained two or more different haplotypes.

The complete ITS2 sequences (428-437 nucleotides), representing 17 haplotypes of 24 clones, were generated from nine specimens of $O$. rietcorreai (Table 2). Absolute divergence values between the ITS2 sequences are shown in Table 3. Differences between haplotypes A, B, $\mathrm{C}$ (homologous cross ${ }^{\lambda} \mathrm{PI} \times \uparrow \mathrm{PI}$ ) varied from 0.2 to $7.1 \%$; differences between haplotypes D, E, F, G, H, I, J (homologous cross ${ }^{\lambda} \mathrm{PB} \times q \mathrm{~PB}$ ) varied from 0.2 to $3.5 \%$; differences between haplotypes K, L, M (heterol-

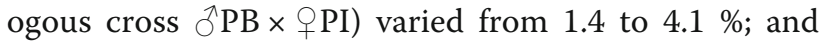
differences between haplotypes N, O, P, Q (heterologous cross $\left.{ }^{\lambda} \mathrm{PI} \times \propto \mathrm{PB}\right)$ varied from 0.2 to $3.5 \%$ (Table 3). Comparing the four cross-mating groups to each other, haplotypes A-C $\left({ }^{\top} \mathrm{PI} \times \uparrow \mathrm{PI}\right)$ differed by 1.4-7.6\% from haplotypes $\mathrm{D}-\mathrm{J}\left({ }^{\wedge} \mathrm{PB} \times \stackrel{\mathrm{PB}}{\mathrm{P}}\right)$, whereas haplotypes $\mathrm{K}-\mathrm{M}\left({ }^{\wedge} \mathrm{PB} \times q \mathrm{PI}\right)$ differed by $0.2-8.5 \%$ from haplotypes N-Q $\left({ }^{\wedge} \mathrm{PI} \times \uparrow \mathrm{PB}\right)$. In addition, haplotypes $\mathrm{A}-\mathrm{C}\left({ }^{7} \mathrm{PI} \times \propto\right.$ PI $)$ differed by $0.7-7.1 \%$ from $\mathrm{K}-\mathrm{M}$ $\left({ }^{\lambda} \mathrm{PB} \times \propto \mathrm{PI}\right)$, and by $0.7-8.5 \%$ from $\mathrm{N}-\mathrm{Q}\left({ }^{\lambda} \mathrm{PI} \times \propto \mathrm{PB}\right)$, whereas haplotypes $\mathrm{D}-\mathrm{J}(\AA \mathrm{PB} \times \uparrow \mathrm{PB})$ differed by $0.2-$ $4.1 \%$ from $\mathrm{K}-\mathrm{M}\left({ }^{\top} \mathrm{PB} \times \uparrow \mathrm{PI}\right)$, and $2.3-8.9 \%$ from $\mathrm{N}-\mathrm{Q}$ $(ð \mathrm{PI} \times \stackrel{P}{ } \mathrm{~PB})$.

A phylogenetic tree inferred by the ITS2 sequences generated in this study (Fig. 7) segregated the ticks of the homologous crosses into distinct clades; i.e. ${ }^{\lambda} \mathrm{PI} \times q$
PI ticks did not share any clade with $\bigcirc \mathrm{PB} \times q \mathrm{~PB}$ ticks. On the other hand, sequences from heterologous crosses $\left({ }^{\lambda} \mathrm{PI} \times \uparrow \mathrm{PB}\right.$ or $\left.{ }^{\lambda} \mathrm{PB} \times \uparrow \mathrm{PI}\right)$ grouped within clades containing sequences from homologous crosses $\left({ }^{\lambda} \mathrm{PI} \times q \mathrm{PI}\right.$ or ${ }^{\wedge} \mathrm{PB} \times \stackrel{P}{ } \mathrm{~PB}$ ticks).

Table 2 Number of clones with respective ITS2 haplotypes generated from purebred (from homologous crosses) or hybrid (from heterologous crosses) male and female $F_{2}$ ticks of two populations of Ornithodoros rietcorreai n. sp.

\begin{tabular}{|c|c|c|c|c|c|}
\hline \multirow{2}{*}{$\begin{array}{l}\text { Cross } \\
(\hat{0} \times p)\end{array}$} & \multirow[t]{2}{*}{ Sex } & \multirow[t]{2}{*}{ Clone } & \multicolumn{3}{|c|}{ ITS2 Haplotype } \\
\hline & & & Code & Size (nt) & GenBank accession no. \\
\hline \multirow[t]{3}{*}{$\mathrm{PI} \times \mathrm{PI}$} & Male & 1 & $A$ & 436 & KX130784 \\
\hline & & 2 & B & 437 & KX130785 \\
\hline & Female & 1 & C & 428 & KX130786 \\
\hline \multirow[t]{10}{*}{$P B \times P B$} & Male & 1 & D & 429 & KX130787 \\
\hline & & 2 & E & 429 & KX130788 \\
\hline & & 3 & G & 428 & KX130790 \\
\hline & Female 1 & 1 & E & 429 & KX130788 \\
\hline & & 2 & । & 435 & KX130792 \\
\hline & & 3 & G & 428 & KX130790 \\
\hline & Female 2 & 1 & J & 435 & KX130793 \\
\hline & & 2 & $\mathrm{H}$ & 430 & KX130791 \\
\hline & & 3 & $\mathrm{~F}$ & 429 & KX130789 \\
\hline & & 4 & E & 429 & KX130788 \\
\hline \multirow[t]{5}{*}{$\mathrm{PB} \times \mathrm{PI}$} & Male & 1 & $\mathrm{H}$ & 430 & KX130791 \\
\hline & Female & 1 & E & 429 & KX130788 \\
\hline & & 2 & M & 434 & KX130796 \\
\hline & & 3 & K & 435 & KX130794 \\
\hline & & 4 & L & 430 & KX130795 \\
\hline \multirow[t]{6}{*}{$\mathrm{Pl} \times \mathrm{PB}$} & Male & 1 & $\mathrm{~N}$ & 428 & KX130797 \\
\hline & & 2 & E & 429 & KX130788 \\
\hline & & 3 & $\mathrm{H}$ & 430 & KX130791 \\
\hline & Female & 1 & P & 428 & KX130799 \\
\hline & & 2 & $\mathrm{O}$ & 428 & KX130798 \\
\hline & & 3 & $Q$ & 429 & KX130800 \\
\hline
\end{tabular}


Table 3 Absolute divergence matrix (\%) between ITS2 sequences (428 to 437-bp) of Ornithodoros rietcorreai n. sp. from four cross-

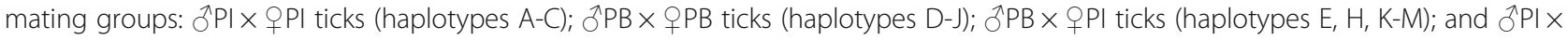
+PB ticks (haplotypes $\mathrm{E}, \mathrm{H}, \mathrm{N}-\mathrm{Q}$ )

\begin{tabular}{|c|c|c|c|c|c|c|c|c|c|c|c|c|c|c|c|c|c|}
\hline $\mathrm{HC}$ & A & B & $C$ & $D$ & $E$ & $\mathrm{~F}$ & G & $\mathrm{H}$ & 1 & $\mathrm{~J}$ & $K$ & $\mathrm{~L}$ & $M$ & $\mathrm{~N}$ & 0 & $P$ & Q \\
\hline $\bar{A}$ & - & & & & & & & & & & & & & & & & \\
\hline B & 0.2 & - & & & & & & & & & & & & & & & \\
\hline C & 6.9 & 7.1 & - & & & & & & & & & & & & & & \\
\hline$D$ & 2.8 & 3.0 & 4.7 & - & & & & & & & & & & & & & \\
\hline E & 2.5 & 2.8 & 4.4 & 0.2 & - & & & & & & & & & & & & \\
\hline$F$ & 2.8 & 3.0 & 4.7 & 0.5 & 0.2 & - & & & & & & & & & & & \\
\hline$G$ & 2.8 & 3.0 & 4.2 & 0.5 & 0.2 & 0.5 & - & & & & & & & & & & \\
\hline $\mathrm{H}$ & 2.3 & 2.5 & 4.7 & 0.5 & 0.2 & 0.5 & 0.5 & - & & & & & & & & & \\
\hline 1 & 1.6 & 1.8 & 7.6 & 3.5 & 3.2 & 3.5 & 3.5 & 3.4 & - & & & & & & & & \\
\hline J & 1.4 & 1.6 & 7.4 & 3.2 & 3.0 & 3.2 & 3.2 & 3.2 & 0.2 & - & & & & & & & \\
\hline K & 0.7 & 0.9 & 6.2 & 2.1 & 1.8 & 2.1 & 2.1 & 2.1 & 1.4 & 1.2 & - & & & & & & \\
\hline L & 3.0 & 3.2 & 5.4 & 1.2 & 0.9 & 1.2 & 1.2 & 0.7 & 4.1 & 3.9 & 2.8 & - & & & & & \\
\hline$M$ & 1.6 & 1.8 & 7.1 & 3.5 & 3.2 & 3.5 & 3.0 & 3.4 & 0.5 & 0.2 & 1.4 & 4.1 & - & & & & \\
\hline $\mathrm{N}$ & 5.1 & 5.3 & 2.1 & 2.8 & 2.6 & 2.8 & 2.3 & 2.8 & 5.8 & 5.5 & 4.4 & 3.5 & 5.3 & - & & & \\
\hline 0 & 5.3 & 5.5 & 2.3 & 3.0 & 2.8 & 3.0 & 2.6 & 3.0 & 6.0 & 5.8 & 4.6 & 3.7 & 5.5 & 0.2 & - & & \\
\hline P & 6.9 & 7.1 & 0.7 & 4.7 & 4.4 & 4.7 & 4.2 & 4.7 & 7.6 & 7.4 & 6.2 & 5.4 & 7.1 & 1.9 & 2.1 & - & \\
\hline Q & 8.2 & 8.5 & 1.6 & 6.1 & 5.8 & 6.1 & 5.6 & 6.0 & 8.9 & 8.7 & 7.6 & 6.7 & 8.5 & 3.3 & 3.5 & 1.4 & - \\
\hline
\end{tabular}

Abbreviation: HC ITS2 haplotype code (see Table 2)

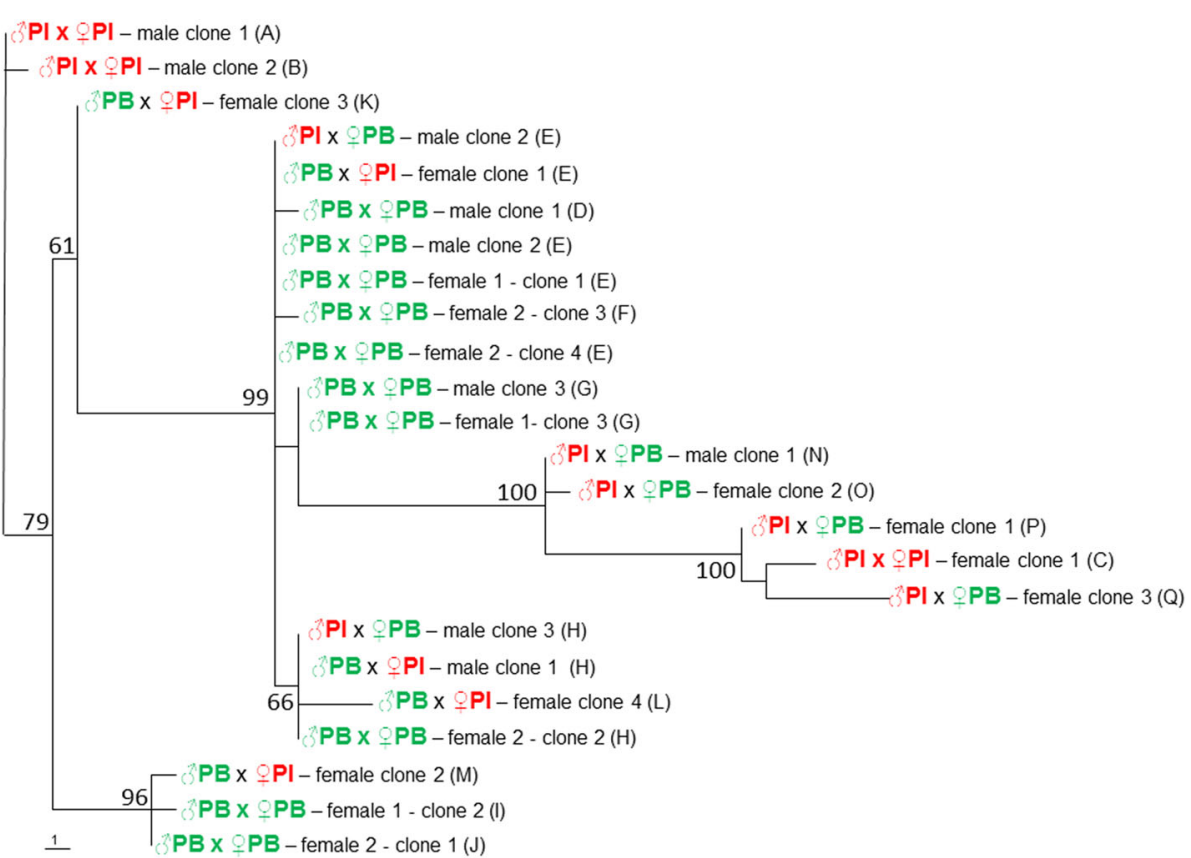

Fig. 7 Maximum parsimony (MP) phylogenetic tree based on complete ITS2 sequences for Ornithodoros rietcorreai n. sp. adult ticks (males and females) derived from cross-mating experiments of two tick populations, one from the State of Piauí (PI) and one from the State of Paraíba (PB). Numbers at nodes are support values derived from bootstrap (500 replicates). Capital letters within parentheses indicate ITS2 haplotype codes (see Table 2) 


\section{Morphological analysis of cross-mating ticks and principal components analysis}

Larvae produced by adult ticks of all four crosses $(\lesssim \mathrm{PB} \times$

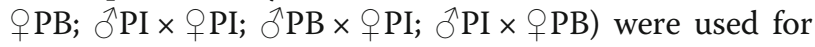
morphological analysis through PCA. Two PCA analyses were carried out with larval morphometric characters (Table 4, Fig. 8). One PCA analysis included purebred ticks from two different populations, Paraíba and Piauí (Fig. 8a), and a second PCA analysis was performed with purebred and hybrid ticks (Fig. 8b). Both PCA analyses showed a clear separation between O. guaporensis, $O$. rioplatensis, $O$. talaje and $O$. rietcorreai. In the PCA analysis that included $O$. rietcorreai larvae only from homologous crosses, the first principal component (explaining $50.92 \%$ of the total variance) was mainly loaded by the variables body length, palpal length, length of hypostome and circumanal setae, and the second component (explaining $29.96 \%$ of the total variance) was principally loaded by the length of basis capituli and dorsal setae (total and dorsolateral). In this analysis, there was a clear separation of the two purebred populations of $O$. rietcorreai, although in a much narrower magnitude than the separation observed between the four tick species (Fig. 8a). In the PCA analysis constructed with purebred (homologous crosses) and hybrid (heterologous crosses) ticks, the first principal component (explaining $55.34 \%$ of the total variance) was mainly loaded by the variables body length (a), pairs of dorsal setae (central), length of basis capituli, length of hypostome and circumanal setae, while the second component (explaining $28.36 \%$ of the total variance) was loaded most heavily by dorsal setae (total and dorsolateral), palpal length (article IV) and hypostome width. In this second analysis, there was no clear separation between the four populations of $O$. rietcorreai, although they were clearly separated from the other three species of Ornithodoros (Fig. 8b).

\section{Discussion}

The argasid O. rietcorreai n. sp. is described from rock cavy habitats in three distinct areas of the Caatinga biome, two in Piauí State, and one in Paraíba State. Among the previous reports of argasid ticks from the rock cavy or its resting places in the Caatinga biome [2-6], at least one [5] was from the same region where we collected ticks in Piauí State. Because it is currently considered that the species $O$. talaje does not occur in Brazil [10], it is possible that at least part of these earlier records from the Caatinga refer to O. rietcorreai.

Because there were a few larval morphological differences between Paraíba (PB) and Piuaí (PI) populations of $O$. rietcorreai (Table 4, Fig. 8), associated with $3.3 \%$ divergence between mitochondrial $16 \mathrm{~S}$ rDNA sequences, we decided to perform cross-mating experiments in order to verify the reproductive compatibility of the two tick populations. Once our results showed that PB and PI ticks were reproductively compatible, we conclude that the morphological and genetic differences observed between Paraíba (PB) and Piuaí (PI) populations are merely intraspecific, excluding the hypothesis that they could represent two different tick species.

Our analysis of ITS2 sequences revealed that this genetic marker is usually represented by distinct haplotypes within the same individual tick, as for example, the presence of four different haplotypes (J, H, F, E) in a single PB-female tick, with divergence values varying from 0.2 to $3.2 \%$ (Tables 2 and 3). Such intragenomic variability of ITS2 sequences, previously reported for Ixodes ticks from North America, may preclude the reliability of ITS2 to build phylogenetic species trees [21]. On the other hand, a number of studies with different tick genera have successfully applied ITS2 sequences to build phylogenetic analyses [22-25]. It appears that the heterogeneity of ITS2 vary greatly among different tick genera or even among different tick species of one genus. For instance, a recent study showed that the ixodid species Amblyomma cajennense (Fabricius, 1787) was represented by a single ITS2 haplotype among 15 geographically distinct populations, whereas a closely related species, Amblyomma sculptum Berlese, 1888, was represented by ten distinct haplotypes from different geographical populations [26]. High levels of ITS2 variability and incomplete homogenization of ITS2 sequences may be caused by introgression associated with hybridization or by incomplete lineage sorting. In this sense, both PCA with purebred ticks and $16 \mathrm{~S}$ rDNA sequence analyses showed that there is a degree of isolation between Paraíba and Piuaí populations of $O$. rietcorreai, but the results of the cross-mating experiment, the analysis of the ITS2 sequences and the PCA performed with purebred and hybrid ticks clearly indicated that the ticks from both populations belong to the same specific entity.

Although ITS2 might not be a suitable molecular marker for phylogenetic inferences of $O$. rietcorreai (due to great heterogeneity), we constructed a phylogenetic tree with all 17 haplotypes generated in the present study (Fig. 7). In this analysis, the populationspecific haplotypes (A-C for PI ticks; D-J for PB ticks) segregated at different clades, suggesting that they could be useful molecular markers for discrimination of the two tick populations. Moreover, the fact that hybrid ticks (from the crosses $\lesssim \mathrm{PI} \times q \mathrm{~PB}$ or $\delta^{\lambda} \mathrm{PB} \times q$ PI) had some of these haplotypes, and also additional haplotypes that grouped in the phylogenetic tree with either of the two purebred ticks $(\lesssim \mathrm{PI} \times q \mathrm{PI}$ or $\lesssim \mathrm{PB} \times$ $q \mathrm{~PB})$, indicate that they are in fact hybrid ticks 
Table 4 Morphometric variables (range and mean values in millimeters) of Ornithodoros rietcorreai larvae from Paraíba ( ${ }^{\lambda} \mathrm{PB} \times \mathrm{P} P \mathrm{~PB}$

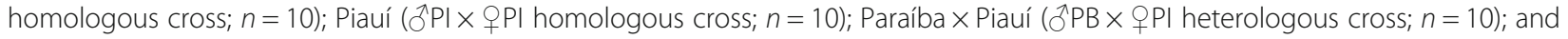
Piauí $\times$ Paraíba $(\widehat{P} \mathrm{PI} \times \stackrel{P B}{ }$ heterologous cross; $n=7)$ utilized in the principal components analysis (PCA)

\begin{tabular}{|c|c|c|c|c|}
\hline & $\begin{array}{l}\text { O. rietcorreai } \\
\text { Paraíba }\end{array}$ & $\begin{array}{l}\text { O. rietcorreai } \\
\text { Piauí }\end{array}$ & $\begin{array}{l}\text { O. rietcorreai } \\
\text { Paraíba } \times \text { Piauí }\end{array}$ & $\begin{array}{l}\text { O. rietcorreai } \\
\text { Piauí } \times \text { Paraíba }\end{array}$ \\
\hline Body length ${ }^{a}$ & $0.723-0.784(0.758)$ & $0.742-0.841(0.797)$ & $0.732-0.762(0.748)$ & $0.723-0.782(0.754)$ \\
\hline Body length $^{\mathrm{b}}$ & $0.396-0.465(0.439)$ & $0.435-0.475(0.457)$ & $0.416-0.445(0.435)$ & $0.435-0.475(0.456)$ \\
\hline Body width & $0.372-0.411(0.393)$ & $0.386-0.465(0.414)$ & $0.346-0.416(0.381)$ & $0.366-0.416(0.393)$ \\
\hline Dorsal plate: length & $0.256-0.293(0.269)$ & $0.268-0.305(0.281)$ & $0.254-0.273(0.263)$ & $0.256-0.278(0.264)$ \\
\hline Dorsal plate: width & $0.151-0.188(0.167)$ & $0.185-0.219(0.197)$ & $0.163-0.195(0.179)$ & $0.166-0.195(0.172)$ \\
\hline Dorsal setae pairs: total & 14 & 14 & 14 & 14 \\
\hline Dorsal setae pairs: dorsolateral & 11 & 11 & 11 & 11 \\
\hline Dorsal setae pairs: central & 3 & 3 & 3 & 3 \\
\hline Central setae 1: length & $0.063-0.085(0.076)$ & $0.073-0.090(0.081)$ & $0.073-0.085(0.079)$ & $0.078-0.085(0.082)$ \\
\hline Central setae 2: length & $0.068-0.075(0.072)$ & $0.068-0.075(0.071)$ & $0.068-0.075(0.071)$ & $0.071-0.085(0.079)$ \\
\hline Central setae 3 : length & $0.075-0.088(0.081)$ & $0.063-0.083(0.078)$ & $0.078-0.093(0.085)$ & $0.075-0.090(0.084)$ \\
\hline Sternal setae 1: length & $0.051-0.063(0.057)$ & $0.063-0.073(0.069)$ & $0.056-0.068(0.061)$ & $0.061-0.068(0.063)$ \\
\hline Sternal setae 2: length & $0.051-0.061(0.057)$ & $0.061-0.068(0.064)$ & $0.056-0.063(0.058)$ & $0.054-0.066(0.061)$ \\
\hline Sternal setae 3 : length & $0.056-0.066(0.060)$ & $0.066-0.075(0.070)$ & $0.053-0.066(0.060)$ & $0.058-0.073(0.064)$ \\
\hline Circumanal setae 1 : length & $0.053-0.061(0.056)$ & $0.056-0.071(0.061)$ & $0.051-0.061(0.057)$ & $0.051-0.063(0.056)$ \\
\hline Circumanal setae 2: length & $0.058-0.073(0.063)$ & $0.065-0.075(0.071)$ & $0.058-0.073(0.065)$ & $0.066-0.073(0.069)$ \\
\hline Circumanal setae 3 : length & $0.073-0.085(0.076)$ & $0.078-0.085(0.082)$ & $0.078-0.083(0.079)$ & $0.075-0.087(0.081)$ \\
\hline Posteromedian setae: length & $0.041-0.049(0.044)$ & $0.044-0.051(0.045)$ & $0.036-0.056(0.042)$ & $0.041-0.048(0.044)$ \\
\hline Postcoxal setae: length & $0.053-0.073(0.063)$ & $0.058-0.071(0.063)$ & $0.053-0.061(0.059)$ & $0.053-0.073(0.063)$ \\
\hline Length of basis capituli $^{c}$ & $0.129-0.134(0.133)$ & $0.136-0.149(0.144)$ & $0.112-0.134(0.126)$ & $0.124-0.142(0.134)$ \\
\hline Length of basis capituli $^{d}$ & $0.154-0.171(0.158)$ & $0.158-0.173(0.169)$ & $0.134-0.158(0.146)$ & $0.149-0.158(0.153)$ \\
\hline Length of capitulum ${ }^{\mathrm{e}}$ & $0.362-0.396(0.380)$ & $0.376-0.406(0.390)$ & $0.362-0.382(0.376)$ & $0.366-0.386(0.374)$ \\
\hline Width of basis capituli & $0.185-0.195(0.191)$ & $0.197-0.210(0.204)$ & $0.171-0.190(0.182)$ & $0.183-0.219(0.200)$ \\
\hline Palpal length & $0.264-0.294(0.278)$ & $0.268-0.288(0.277)$ & $0.256-0.274(0.262)$ & $0.267-0.287(0.276)$ \\
\hline Length article I & 0.049.0.061 (0.054) & $0.058-0.061(0.059)$ & $0.049-0.061(0.053)$ & $0.049-0.061(0.056)$ \\
\hline Length article II & $0.083-0.100(0.092)$ & $0.083-0.085(0.084)$ & $0.085-0.100(0.094)$ & 0.083-0.097 (0.089) \\
\hline Length article III & $0.088-0.107(0.100)$ & $0.097-0.100(0.098)$ & $0.097-0.110(0.104)$ & $0.098-0.107(0.100)$ \\
\hline Length article IV & $0.036-0.044(0.039)$ & $0.039-0.044(0.041)$ & $0.039-0.046(0.041)$ & $0.034-0.044(0.039)$ \\
\hline Width article I & $0.027-0.039(0.030)$ & $0.027-0.029(0.028)$ & $0.027-0.029(0.028)$ & $0.027-0.032(0.028)$ \\
\hline Width article ॥ & $0.034-0.044(0.038)$ & $0.034-0.036(0.035)$ & $0.036-0.039(0.037)$ & $0.034-0.036(0.035)$ \\
\hline Width article III & $0.024-0.032(0.028)$ & $0.029-0.034(0.031)$ & $0.027-0.032(0.029)$ & $0.031-0.034(0.032)$ \\
\hline Width article IV & $0.019-0.024(0.022)$ & $0.019-0.022(0.020)$ & $0.019-0.022(0.021)$ & $0.019-0.022(0.020)$ \\
\hline Hypostome: length ${ }^{f}$ & $0.232-0.254(0.247)$ & $0.237-0.256(0.249)$ & $0.236-0.246(0.240)$ & $0.227-0.241(0.236)$ \\
\hline Hypostome: length ${ }^{9}$ & $0.190-0.210(0.202)$ & $0.202-0.212(0.206)$ & $0.207-0.224(0.213)$ & $0.188-0.202(0.196)$ \\
\hline Hypostome: width at midlength & $0.039-0.046(0.043)$ & $0.041-0.051(0.046)$ & $0.043-0.049(0.044)$ & $0.041-0.046(0.043)$ \\
\hline Hypostome: width at the base & $0.044-0.053(0.049)$ & $0.044-0.056(0.050)$ & $0.046-0.058(0.051)$ & $0.040-0.056(0.050)$ \\
\hline Apical dental formula & 3 & 3 & 3 & 3 \\
\hline Median dental formula & 3 & 3 & 3 & 3 \\
\hline Basal dental formula & 2 & 2 & 2 & 2 \\
\hline Denticles in hypostomal row 1 & 20 to 21 & 18 to 20 & 20 to 22 & 20 to 22 \\
\hline Denticles in hypostomal row 2 & 20 to 21 & 18 to 19 & 19 to 21 & 20 to 22 \\
\hline
\end{tabular}


Table 4 Morphometric variables (range and mean values in millimeters) of Ornithodoros rietcorreai larvae from Paraíba ( $\widehat{D}^{\lambda} \mathrm{PB} \times \mathrm{PPB}$

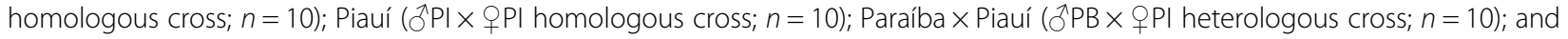
Piauí $\times$ Paraíba $(\widehat{O P I} \times$ PB heterologous cross; $n=7)$ utilized in the principal components analysis (PCA) (Continued)

\begin{tabular}{lllll}
\hline & $\begin{array}{l}\text { O. rietcorreai } \\
\text { Paraíba }\end{array}$ & $\begin{array}{l}\text { O. rietcorreai } \\
\text { Piauí }\end{array}$ & $\begin{array}{l}\text { O. rietcorreai } \\
\text { Paraíba } \times \text { Piauí }\end{array}$ & $\begin{array}{l}\text { O. rietcorreai } \\
\text { Piauí } \times \text { Paraíba }\end{array}$ \\
\hline Denticles in hypostomal row 3 & 12 to 15 & 13 to 14 & 13 to 16 & 13 to 15 \\
Tarsus I: length & $0.158-0.190(0.167)$ & $0.190-0.202(0.195)$ & $0.146-0.158(0.155)$ & $0.166-0.171(0.168)$ \\
Tarsus I: width & $0.049-0.061(0.056)$ & $0.061-0.068(0.063)$ & $0.049-0.061(0.056)$ & $0.058-0.063(0.061)$ \\
\hline
\end{tabular}

ancluding capitulum

${ }^{\mathrm{b}}$ Not including capitulum

cLength of basis capituli: measured from the posterior margin of basis capituli to posthypostomal setae 1 (Ph1)

dLength of basis capituli: measured from the posterior margin of basis capituli to insertion of hypostome

'Length of capitulum: measured from the posterior margin of basis capituli to the anterior end of hypostome

f Measured to Ph1

${ }^{9}$ Measured to the posterior end of the toothed portion
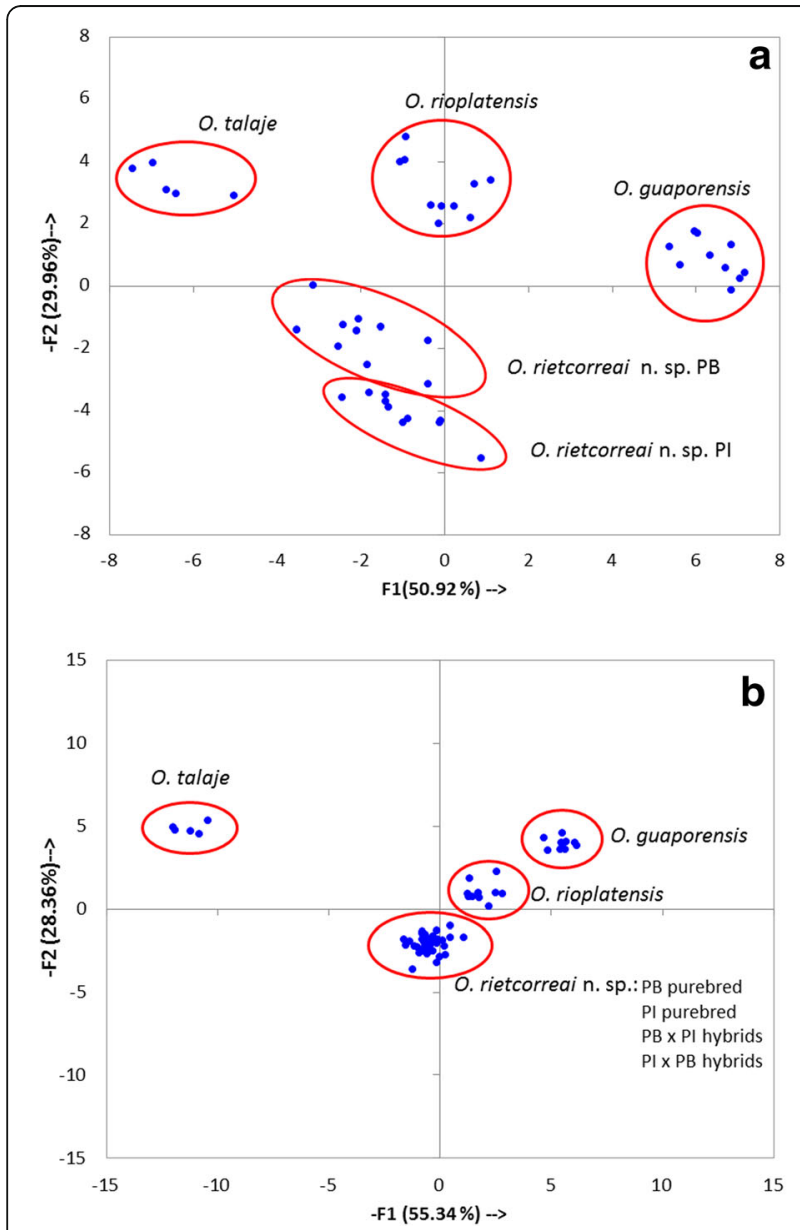

Fig. 8 Principal components analysis (PCA) of the body and setal measurements of the lanvae of Ornithodoros rietcorreai n. sp., Ornithodoros guaporensis, Ornithodoros rioplatensis and Ornithodoros talaje, using the features detailed in Table 4. Morphometric variables for the larvae of $O$. guaporensis, $O$. rioplatensis and $O$. talaje were retrieved from Nava et al. [17]. Each point represents the position of a measured specimen in the reduced morphometric space. a Analysis including $O$. rietcorreai purebred larvae from homologous crosses of Paraiba (PB) and of Piauí (PI). b Analysis including $O$. rietcorreai purebred larvae from homologous crosses of Paraíba (PB) and Piauí (PI), and hybrid

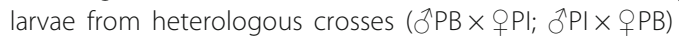

derived from the crosses of the two tick populations. It must be emphasized that until the completion of the present study, the only ITS2 sequence for argasid species available on GenBank was a 583 bp sequence for Argas africolumbae Hoogstraal, Kaiser, Walker, Ledger, Converse \& Rice, 1975 (KF984488), which did not align with our $O$. rietcorreai sequences, precluding any analyses of the $O$. rietcorreai ITS2 sequences with other argasid tick species.

\section{Conclusion}

Ornithodoros rietcorreai is described as a new species associated with $K$. rupestris in Brazil, increasing the Brazilian tick fauna to 70 species.

\section{Acknowledgments}

We are grateful to Dr. Sheila O. Silva and Dr. Sueli A. T. Miyagi (University of São Paulo) for their technical assistance in the molecular biology methods.

\section{Funding}

This work was financially supported by Fundação de Amparo a Pesquisa do Estado de São Paulo (FAPESP), Conselho Nacional de Desenvolvimento Científico e Tecnológico (CNPq), and Coordenação de Aperfeiçoamento de Pessoal de Nível Superior (CAPES/PROEX 2327/2015).

\section{Availability of data and materials}

Ticks investigated in this study are deposited as listed under "Type-specimens" and sequences are deposited in the GenBank database under accession numbers KX130781-KX130782 (16S rRNA gene) and KX130784-KX130800 (ITS2).

\section{Authors' contributions}

$M B L, S N, M C H$, JMV conducted the field studies and wrote the manuscript. AM and ARMB performed molecular and phylogenetic analyses. MBL, SN, PHN, JMV conducted morphological analyses. All authors read and approved the final manuscript.

\section{Competing interests}

The authors declare that they have no competing interests.

\section{Consent for publication}

Not applicable.

\section{Ethics approval and consent to participate}

This work has been approved by the Instituto Chico Mendes (ICMBio), Brazil (authorization numbers 34237-1, 36585-2), and the Ethics Committee on Research of the Universidade Federal do Vale do São Francisco, Brazil (project number 0011/161012). 


\section{Author details}

'Departamento de Medicina Veterinária Preventiva e Saúde Animal, Faculdade de Medicina Veterinária e Zootecnia, Universidade de São Paulo, Av. Prof. Orlando Marques de Paiva 87, São Paulo 05508-270, Brazil. ${ }^{2}$ Instituto Nacional de Tecnología Agropecuaria, Estación Experimental Agropecuaria Rafaela and Consejo Nacional de Investigaciones Científicas y Técnicas, CC 22, CP 2300 Rafaela, Santa Fe, Argentina. ${ }^{3}$ Universidade de Santo Amaro, R. Prof. Enéas de Siqueira Neto 340, São Paulo 04829-300, Brazil. ${ }^{4}$ Instituto Latino-Americano de Ciências da Vida e da Natureza, Universidade Federal da Integração Latino-Americana, Av. Tarquínio Joslin dos Santos 1000, Foz do Iguaçu, Paraná 85870-901, Brazil. ${ }^{5}$ Universidade Federal do Vale do São Francisco, Campus de Ciências Agrárias, Rodovia BR 407, Km 12, Lote 543 Projeto de Irrigação Senador Nilo Coelho, s/n, Petrolina, Pernambuco 56300-990, Brazil. 'Laboratorio de Vectores y Enfermedades Transmitidas, Facultad de Veterinaria, CENUR Litoral Norte, Salto, Universidad de la República, Rivera 1350, CP 50000 Salto, Uruguay.

Received: 19 May 2016 Accepted: 14 September 2016

Published online: 21 September 2016

\section{References}

1. Reis NR, Pearcchi AL, Pedro WA, Lima IP. Mamíferos do Brasil. Londrina: Nelio R. dos Reis; 2006. http://www.uel.br/pos/biologicas/pages/arquivos/ pdf/Livro-completo-Mamiferos-do-Brasil.pdf. Accessed 28 Apr 2016.

2. Aragão HB. Notas sobre algumas coleções de carrapatos brasileiros. Mem Inst Oswaldo Cruz. 1913:5:263-70.

3. Aragão HB. Notas ixodidologicas. Rev Mus Paul. 1918;10:375-417.

4. Fonseca F. Notas de Acarologia XLIV. Inquérito sobre a fauna acarológica de parasitas no nordeste do Brasil. Mem Inst Butantan. 1958;28:99-186.

5. Neiva A, Penna B. Viagem científica pelo norte da Bahia, sudoeste de Pernambuco, sul do Piauí e de norte a sul de Goiaz. Mem Inst Oswaldo Cruz. 1916;8:74-224

6. Oba MSP, Baggio D. Ocorrência de Ornithodoros talaje Guérin Meneville, 1849, (Acari: Argasidae) na localidade de Santo Inácio. Bahia Arq Inst Biol. 1977:44:107-9.

7. Kohls GM, Sonenshine DE, Clifford CM. The systematics of the subfamily Ornithodorinae (Acarina: Argasidae). II. Identification of the larvae of the Western Hemisphere and description of three new species. Ann Entomol Soc Am. 1965:58:331-64.

8. Jones EK, Clifford CM. The systematics of the subfamily Ornithodorinae (Acarina: Argasidae).V. A revised key to larval Argasidae of the western hemisphere and description of seven new species of Ornithodoros. Ann Entomol Soc Am. 1972;65:730-40.

9. Labruna MB, Venzal JM. Carios fonsecai sp. nov. (Acari, Argasidae), a bat tick from the centralwestern region of Brazil. Acta Parasitol. 2009;54:355-63.

10. Venzal JM, Estrada-Peña A, Mangold A, Gonzalez-Acuña D, Guglielmone AA. The Ornithodoros (Alectorobius) talaje species group (Acari: Ixodida: Argasidae): Description of Ornithodoros (Alectorobius) rioplatensis n. sp. from southern South America. J Med Entomol. 2008;45:832-40.

11. Labruna MB, Marcili A, Ogrzewalska M, Barros-Battesti DM, Dantas-Torres F, Fernandes AA, et al. New records and human parasitism by Ornithodoros mimon (Acari: Argasidae) in Brazil. J Med Entomol. 2014;51:283-7.

12. Estrada-Peña A, Venzal JM, González-Acuña D, Mangold AJ, Guglielmone AA. Notes on New World Persicargas ticks (Acari: Argasidae) with description of female Argas (P.) keiransi. J Med Entomol. 2006;43:801-9.

13. Nava S, Mangold AJ, Mastropaolo M, Venzal JM, Oscherov EB, Guglielmone AA. Amblyomma boeroi n. sp. (Acari: Ixodidae), a parasite of the Chacoan peccary Catagonus wagneri (Rusconi) (Artiodactyla: Tayassuidae) in Argentina. Syst Parasitol. 2009;73:161-74

14. Corwin DC, Clifford CM, Keirans JE. An improved method for cleaning and preparing ticks for examination with the scanning electron microscope. J Med Entomol. 1979;16:352-3.

15. Mangold AJ, Bargues MD, Mas-Coma S. Mitochondrial $16 \mathrm{~S}$ rDNA sequences and phylogenetic relationships of species of Rhipicephalus and other tick genera among Metastriata (Acari: Ixodidae). Parasitol Res. 1998;84:478-84.

16. Swofford DL. PAUP: Phylogenetic analysis using parsimony. Beta Version 4. 0b10. Sunderland: Sinauer and Associates; 2002.

17. Nava S, Venzal JM, Terassini FA, Mangold AJ, Camargo LM, Casás G, Labruna MB. Ornithodoros guaporensis (Acari, Ixodida: Argasidae), a new tick species from the Guapore River Basin in the Bolivian Amazon. Zootaxa. 2013;3666:579-90.
18. Clifford CM, Kohls GM, Sonenshine DE. The systematics of the subfamily Ornithodorinae (Acarina: Argasidae). I. The genera and subgenera. Ann Entomol Soc Am. 1964;57:429-37.

19. Muñoz-Leal S, Venzal JM, González-Acuña D, Nava S, Lopes MG, Martins TF, et al. A new species of Ornithodoros (Acari: Argasidae) from desert areas of northern Chile. Ticks Tick Borne Dis. 2016 (epub ahead of print).

20. Venzal JM, Nava S, Mangold AJ, Mastropaolo M, Casás G, Guglielmone AA. Ornithodoros quilinensis sp. nov. (Acari, Argasidae), a new tick species from the Chacoan region in Argentina. Acta Parasitol. 2012;57:329-36.

21. Rich SM, Rosenthal BM, Telford 3rd SR, Spielman A, Hartl DL, Ayala FJ. Heterogeneity of the internal transcribed spacer (ITS-2) region within individual deer ticks. Insect Mol Biol. 1997;6:123-9.

22. Barker SC. Distinguishing species and populations of rhipicephaline ticks with ITS2 ribosomal RNA. J Parasitol. 1998;84:887-92.

23. Fukunaga M, Yabuki M, Hamase A, Oliver Jr JH, Nakao M. Molecular phylogenetic analysis of ixodid ticks based on the ribosomal DNA spacer, internal transcribed spacer 2, sequences. J Parasitol. 2000;86:38-43.

24. Murrell A, Campbell NJ, Barker SC. Recurrent gains and losses of large (84-109 bp) repeats in the rDNA internal transcribed spacer 2 (ITS2) of rhipicephaline ticks. Insect Mol Biol. 2001;10:587-96.

25. Beati L, Nava S, Burkman EJ, Barros-Battesti DM, Labruna MB, Guglielmone $\mathrm{AA}$, et al. Amblyomma cajennense (Fabricius, 1787) (Acari: Ixodidae), the Cayenne tick: phylogeography and evidence for allopatric speciation. BMC Evol Biol. 2013;13:267

26. Martins TF, Barbieri AR, Costa FB, Terassini FA, Camargo LM, Peterka CR, et al. Geographical distribution of Amblyomma cajennense (sensu lato) ticks (Parasitiformes: Ixodidae) in Brazil, with description of the nymph of $A$. cajennense (sensu stricto). Parasit Vectors. 2016;9:186.

\section{Submit your next manuscript to BioMed Central and we will help you at every step:}

- We accept pre-submission inquiries

- Our selector tool helps you to find the most relevant journal

- We provide round the clock customer support

- Convenient online submission

- Thorough peer review

- Inclusion in PubMed and all major indexing services

- Maximum visibility for your research

Submit your manuscript at www.biomedcentral.com/submit
Biomed Central 